\title{
Defining the "Public Act" Requirement in the Act of State Doctrine
}

\author{
Lynn E. Parseghian $\dagger$
}

The act of state doctrine provides that U.S. courts will not question the validity of the public acts of a foreign sovereign undertaken within its own territory. " But what is a "public act"? Should a deposed dictator who raided public coffers while in power be allowed to raise an act of state defense in a suit brought by the new government? ${ }^{2}$ Should the actions of a foreign official who accepted bribes in exchange for the grant of an oil concession be shielded from judicial scrutiny?3 The Supreme Court has confirmed that to qualify as an act of state, the conduct must be the "public act" of the sovereign, but the justices have disagreed about how this phrase should be interpreted. ${ }^{4}$

The problem of defining the public act requirement has become more pressing since W.S. Kirkpatrick \& Co., Inc. v Environmental Tectonics Corp., Int'l, ${ }^{5}$ in which the Court declined to resolve whether acceptance of a bribe was a public act, although the issue was squarely presented. Instead of defining the public act requirement, the Court announced a new threshold test for the act of state doctrine that falls short of clarifying the doctrine's scope. ${ }^{6}$

$\dagger$ B.A. 1987, University of Pennsylvania; J.D. Candidate 1991, The University of Chicago.

1 Underhill v Hernandez, 168 US 250, 252 (1897), is the earliest U.S. case in which the Court used the phrase "act of state." For the leading contemporary statement of the doctrine, see Banco Nacional de Cuba v Sabbatino, 376 US 398 (1964).

2 The Marcos cases exemplify the contemporary significance of this question. See $R e$ public of Philippines v Marcos, 806 F2d 344 (2d Cir 1986); and Republic of Philippines $v$ Marcos, 818 F2d 1473 (9th Cir 1987), rev'd en banc, 862 F2d 1355 (9th Cir 1988). The Philippine government brought these suits against former President Marcos to recover property located in New York and Hawaii allegedly acquired through Marcos's theft of funds and property belonging to the Philippine government.

${ }^{3}$ See Clayco Petroleum Corp. v Occidental Petroleum Corp., 712 F2d 404 (9th Cir 1983) (per curiam). See also text at notes 57-59.

1 See Alfred Dunhill of London, Inc. $v$ Republic of Cuba, 425 US 682 (1976) (plurality opinion). For a general discussion of other issues in the public act debate, see Joseph W. Dellapenna, Deciphering the Act of State Doctrine, 35 Vill L Rev 1, 55 (1990).

- 110 S Ct 701 (1990).

I Id. 
The lower courts have diverged on this key question of whether abuses of government authority are public acts. Some courts have defined "public act" expansively to include abuses of sovereign authority for private purposes, as well as acts by officials that contravene or exceed their responsibilities. ${ }^{7}$ Other courts have taken a restrictive approach, defining "public act" to exclude such abuses of authority by foreign officials. ${ }^{8}$ Yet no court has elaborated upon or defended its view of the public act requirement in terms of the broader theoretical concerns that animate the act of state doctrine.

This Comment argues that the first step in every case involving an act of state question should be to address whether a public act of a sovereign is at issue. ${ }^{8}$ Courts should define public act in a way that is most consistent with the doctrine's underlying purposes.

Section I sets forth the basic disputes about the doctrine's purposes and theoretical underpinnings. Rather than attempting to provide any unitary theory, this Comment argues that the doctrine is best understood as serving a variety of functions and incorporating a range of policy considerations. ${ }^{10}$ Section II details the Supreme Court's limited efforts to define the public act requirement, and the divergent approaches that have resulted in the lower courts. It shows that this split stems largely from uncertainty over the doctrine's conceptual underpinnings.

Section III offers a new approach to the public act requirement, founded upon the theory of the doctrine's framework and policy goals outlined in Section I. This Comment argues that the best definition is a narrow one, emcompassing only the authorized or ratified acts of government officials undertaken for public purposes. This definition, like the restrictive approach of many lower courts, excludes cases in which a government official has acted ei-

7 Some decisions have explicitly held that such abuses fall within the scope of the doctrine. Banco de Espana v Federal Reserve Bank of New York, 114 F2d 438, 443-44 (2d Cir 1940); Marcos, 818 F2d 1473 (9th Cir 1987), rev'd en banc, 862 F2d 1355. Others have included them implicitly. O.N.E. Shipping Ltd. v Flota Mercante Grancolombiana, S.A., 830 F2d 449 (2d Cir 1987); Clayco Petroleum Corp., 712 F2d 404.

a Jimenez v Aristeguieta, 311 F2d 547, 557-58 (5th Cir 1962); Marcos, 806 F2d at 359 (2d Cir 1986); Galu v Swissair, 873 F2d 650, 654 (2d Cir 1989); Sharon v Time, Inc., 599 F Supp 538 (S D NY 1984).

- The first commentator to suggest such an approach was Charles R. McManis, Questionable Corporate Payments Abroad: An Antitrust Approach, 86 Yale L J 215 (1976) (arguing by analogy to the state action doctrine in domestic antitrust law).

${ }^{10}$ This theory was recently proposed by Anne-Marie Burley, Mixed Motives: Kirkpatrick v Environmental Tectonics at 29-31 (unpublished draft, 1990) (on file with U Chi L Rev). 
ther from purely private motives, or in ways that contravene or exceed the official's responsibilities. ${ }^{11}$ Finally, the Comment provides a set of specific criteria for application of the requirement.

\section{The Doctrinal Underpinnings: Evolution and Debate}

The act of state doctrine is deceptively easy to summarize: U.S. courts will not question the validity of public acts of a foreign sovereign undertaken within its own territory. ${ }^{12}$ In fact, its brief formulation masks a welter of complex issues. Drawing predominantly upon the Supreme Court's most influential act of state cases, this Section distills the basic purposes and structure of the doctrine. The Section shows that act of state cases address concerns of respect for foreign sovereigns, separation of powers, and justiciability. The Section then describes how the flexible balancing test the Court has adopted to apply the doctrine has been effectively undermined by the absence of a clearly defined public act requirement.

\section{A. The Purposes of the Doctrine}

An examination of the Supreme Court's act of state decisions reveals that the doctrine has evolved in order to address three specific concerns: respect for foreign sovereigns, separation of powers, and justiciability. ${ }^{13}$ These concerns now provide the most fundamental rationales for the doctrine. Individual decisions often emphasize one of these rationales to the exclusion of the others, yet each has played a vital role in the development of the doctrine, and each reflects important domestic and international concerns.

11 For clarity and consistency, this Comment will refer to acts that are unauthorized (or unratified) or done for private purposes as "non-sovereign" acts. The Comment avoids the label "private acts" because some courts currently use the terms "public" and "private" to distinguish sovereign "commercial" or trading activity from purely "governmental" acts. Because this Comment will refer to government "officials" throughout, it will not adopt the terms "official" and "unofficial," which some scholars use to distinguish between authorized and unauthorized conduct.

12 Sabbatino, 376 US at 401; Underhill, 168 US at 252. Although considerable disagreement exists over how to characterize the doctrine, it is most commonly thought of as a rule of abstention. See Dunhill, 425 US at 697; First National City Bank v Banco Nacional de Cuba, 406 US 759, 775-76 (1972) (plurality opinion); see also Robert Delson, The Act of State Doctrine-Judicial Deference or Abstention?, 66 Am J Intl L 82, 87-89 (1972) (early cases resulted in abstention).

13 Burley, Mixed Motives at 29-31 (cited in note 10). Compare Dellapenna, 35 Vill L Rev at 31 n 176 (cited in note 4). 
1. Respect for foreign sovereigns.

In its earliest formulation, the act of state doctrine was founded upon the international law principle that every nation should show respect for and courtesy toward foreign sovereigns' acts, laws, and institutions. This principle, known as comity, ${ }^{14}$ was the basis for the decision in the 1897 case of Underhill $v$ Hernandez, the Supreme Court's first act of state opinion: "[e]very sovereign State is bound to respect the independence of every other sovereign State, and the courts of one country will not sit in judgment on the acts of the government of another done within its own territory." 15 The Court took heed of this principle and affirmed the dismissal of a suit brought by a U.S. citizen, Underhill, who sought damages for wrongful imprisonment from a Venezuelan revolutionary military leader, Hernandez. In finding that the presence of an act of state barred adjudication, the Court relied on the U.S. government's retroactive recognition of the Venezuelan revolutionary government, and Hernandez's lack of a private motive. ${ }^{16}$ Therefore, the doctrine applied because Hernandez's actions bore the stamp of sovereign approval, and comity was due. ${ }^{17} \mathrm{Be}$ cause the comity principle affords courts flexibility in determining whether adjudication will "imperil the amicable relations"18 between the U.S. and the foreign government, it remains an important guide in applying the act of state doctrine. ${ }^{19}$

\section{Separation of powers.}

The comity rationale has been supplemented by separation of powers concerns, first enunciated in the act of state context in Banco Nacional de Cuba v Sabbatino. ${ }^{20}$ Sabbatino arose when

\footnotetext{
14 For more on comity, see Ian Brownlie, Principles of Public International Law 31 (Oxford, 3d ed 1979).

$16168 \mathrm{US}$ at 252.

${ }^{18}$ Id at 254.

17 Both the rationale and result of Underhill were confirmed by Oetjen $v$ Central Leather Co., 246 US 297 (1918) and Ricaud v American Metal Co., 246 US 304 (1918), companion cases in which the Court concluded that the principle established in Underhill "rests upon the highest considerations of international comity and expediency." Oetjen, 246 US at 303-04.

18 Oetjen, 246 US at 303.

${ }^{10}$ It is important to distinguish the act of state doctrine from sovereign immunity, which is a jurisdictional defense. Underhill did not hold that a foreign sovereign cannot be sued in a U.S. court. Moreover, the doctrine can be asserted not only by foreign sovereigns on their own behalf, but also by government officials and private parties seeking to avoid adjudication of matters touching on sovereign activities. O.N.E. Shipping, 830 F2d at 452. ${ }^{20} 376$ US 398 (1964).
} 
Fidel Castro issued a decree expropriating U.S.-owned assets in retaliation for reductions in the quota for sugar exports to the U.S. Applying the act of state doctrine to bar the suit, the Court held that U.S. courts could not examine the validity of the expropriation decree. The Court surveyed its previous act of state decisions and decided that although neither international law nor the Constitution compelled the doctrine, it had " 'constitutional' underpinnings."21 In a passage that has profoundly influenced act of state jurisprudence, the Court stated:

[The doctrine] arises out of the basic relationships between branches of government in a system of separation of powers. It concerns the competency of dissimilar institutions to make and implement particular kinds of decisions in the area of international relations. The doctrine ... expresses the strong sense of the Judicial Branch that its engagement in the task of passing on the validity of foreign acts of state may hinder rather than further this country's pursuit of goals both for itself and for the community of nations as a whole in the international sphere. ${ }^{22}$

This separation of powers rationale arose in recognition of the delicate balance that must be achieved between the Judiciary and Executive branches in matters touching on foreign relations. By modifying the basis for the doctrine to render it sensitive to separation of powers concerns, the Court steered between questioning the validity of the act on the one hand, and giving it force and effect in a U.S. court on the other. ${ }^{23}$

Some courts have incorrectly viewed the Sabbatino separation of powers rationale as supplanting rather than supplementing the Underhill comity theory. ${ }^{24}$ As a result, the domestic concerns that the separation of powers rationale embodies have sometimes overshadowed the important international concerns reflected in the

21 Id at $421-23,427$.

22 Id at 423.

${ }^{23}$ See Burley, Mixed Motives at 37 (cited in note 10). Courts generally have not allowed movants simply to invoke the phrase "separation of powers" in abstract terms. Rather, movants must show that adjudication of the claim poses a demonstrable, not merely speculative, threat to the conduct of foreign relations. Phoenix Canada Oil Co., Ltd. v Texaco, 749 F Supp 525, 532 (S D NY 1990), citing Environmental Tectonics, 847 F2d at 1061; Mannington Mills, Inc. $v$ Conglomerate Corp., 595 F2d 1287, 1294 (3d Cir 1979); and Williams v Curtiss-Wright Corp., 694 F2d 300, 303 (3d Cir 1982). See also Timberlane Lumber Co. $v$ Bank of America, 549 F2d 597, 607 (9th Cir 1976) (depth and nature of sovereign interest is relevant).

${ }^{24}$ See, for example, Clayco Petroleum Corp., 712 F2d at 409. 
comity principle. Both strands of reasoning remain intact, however, and both are important to the doctrine's capacity to protect domestic and international interests. ${ }^{25}$

\section{Justiciability.}

Finally, the doctrine implicates justiciability concerns..$^{26}$ When confronting cases with foreign policy overtones, courts seek to preserve their institutional integrity by avoiding adjudication of claims for which legal standards are lacking. The concern is embarrassment to the Judiciary itself, rather than embarrassment to the Executive or to foreign governments. The justiciability rationale, at least implicitly, underlies a number of act of state decisions. ${ }^{27}$ In deciding against adjudication, the Sabbatino Court expressly relied not only on separation of powers concerns but also on the lack of judicially manageable standards. The Court decided that the expropriation dispute was more ideological than legal, since expropriation is not clearly prohibited under international law. ${ }^{28}$ Justiciability concerns are present, therefore, when the claim that implicates an act of state is not well-established under domestic or international law.

The doctrine rests upon this tripartite set of purposes. Comity, separation of powers, and justiciability concerns capture the full range of domestic and international issues that confront courts in act of state cases. These concerns guide this Comment's efforts to clarify and strengthen the doctrine by refining the public act definition.

\footnotetext{
${ }^{25}$ Indeed, Sabbatino itself suggested such harmony by noting that the Court was concerned "for the community of nations as a whole in the international sphere." 376 US at 423. Moreover, the Court has reaffirmed that the concept of comity may justify application of the doctrine. First National City Bank, 406 US at 765. See also F. \& H.R. FarmanFarmaian v Harza Engineering Co., 882 F2d 281, 286-87 (7th Cir 1989) (comity and separation of powers are the dual rationales of the doctrine); Bandes $v$ Harlow \& Jones, Inc., 852 F2d 661, 666 (2d Cir 1988) (doctrine reflects comity and separation of powers concerns).

${ }^{28}$ See Burley, Mixed Motives at 34-35 (cited in note 10); Daniel C.K. Chow, Rethinking the Act of State Doctrine: An Analysis in Terms of Jurisdiction to Prescribe, 62 Wash L Rev 397, 421-23 (1987).

${ }^{27}$ Compare Int'l Ass'n of Machinists v OPEC, 649 F2d 1354, 1361 (9th Cir 1981) ("We are reluctant to allow judicial interference in an area so void of international consensus."), with Marcos, 806 F2d at 356-57 (suit no less justiciable than any other involving theft and misappropriation). See also Industrial Investment Development Corp. v Mitsui \& Co., Ltd., 594 F2d 48, 54 (5th Cir 1979) (distinguishing applicability of doctrine to expropriation claims from applicability to antitrust disputes).

${ }^{28}$ Sabbatino, 376 US at $429,430 \&$ n $34,434-35$.
} 
B. The Structure of the Doctrine: Balancing Test or Rule with Exceptions?

The question of how flexible the doctrine should be has provided a further source of disagreement that bears significantly on the public act issue. This subsection briefly describes this controversy and argues that a clearer definition of "public act" would limit application of the doctrine while still offering courts sufficient flexibility.

Initially, Underhill and the cases that followed provided little in the way of a coherent test that courts could use to decide when to apply the doctrine. But Sabbatino introduced a novel approach. The Court decided that the concerns underlying the doctrine were best served not by a uniform or rigid rule, but rather by a flexible balancing test. ${ }^{2 \theta}$ The test included three factors that courts should balance in deciding whether to apply the act of state doctrine: the degree of codification or consensus concerning a particular area of international law, the implications of the issue for U.S. foreign relations, and whether the government at issue was still in power. ${ }^{30}$

Uncomfortable with the open-endedness of the Sabbatino balancing test, some Justices opted for a more rule-oriented approach and attempted to limit the balancing test by adopting exceptions. These Justices were successful in gathering pluralities in the Court in favor of limiting the doctrine by adopting exceptions to its application. ${ }^{31}$ Many lower courts followed the lead of these Justices and have developed their own exceptions to the doctrine. ${ }^{32}$ None of these exceptions has garnered the support of a majority of the Supreme Court, however. ${ }^{33}$ In fact, the Court's continuing approval of

20 Id at 427-28 (court expressly refused to lay down "an inflexible and all-encompassing rule"). The Court rendered a narrow holding applicable only to takings of property, but its articulation of the balancing test in dicta has become highly influential in other cases.

${ }^{30}$ Id at 428.

"See, for example, Alfred Dunhill of London, Inc. $v$ Republic of Cuba, 425 US 682, 695-706 (1976) (plurality opinion) (endorses a commercial act exception); First National City Bank, 406 US at 764-70 (recognizes an executive suggestion exception-also known as the "Bernstein exception"-to be applied where the Executive expressly states that the case will not "embarrass" its conduct of foreign policy).

${ }^{32}$ See, for example, Kalamazoo Spice Extraction Co. v Ethiopia, 729 F2d 422 (6th Cir 1984) (recognition of a treaty exception); Arango v Guzman Travel Advisors Corp., 621 F2d 1371, 1380-82 (5th Cir 1980) (commercial exception); Sage Int'l, Ltd. v Cadillac Gage Co., 534 F Supp 896, 909-10 (E D Mich 1981) (corruption exception).

s3 Some would argue that the restrictive view of the public acts requirement amounts to endorsement of an exception to the doctrine for private acts. However, as Section III argues, the restrictive view is better understood as providing a refined definition of the acts to which the doctrine applies, rather than carving out an exception. In so doing, the restrictive view remains more faithful to the flexible balancing approach mandated by Sabbatino. 
the Sabbatino balancing framework can be inferred both from the frequency with which its balancing test is cited and applied and by negative implication from the Court's reluctance to embrace any of the proffered exceptions. ${ }^{34}$

Critics of the balancing test have pointed to the indeterminacy of its application to justify these exceptions. ${ }^{35}$ The open-endedness of the Sabbatino balancing test has resulted in part from the lack of a clear delineation of the scope of the public acts requirement. If application of the balancing test had been clearly circumscribed by the exclusion of non-sovereign acts, the need for exceptions would have been reduced, and the doctrine itself would likely be more coherent. Unfortunately, the debate over the exceptions has distracted courts and commentators from defining a precise method for identifying public acts. The next Section examines the courts' fitful attempts to identify those acts.

\section{Judicial Formulations of the Public Act Requirement}

The Supreme Court has said surprisingly little on the fundamental question of what types of acts constitute public acts of a sovereign. Lacking guidance, lower courts have adopted contradictory positions in several high-profile, politically sensitive cases. Some decisions have included abuses of authority within the scope of the doctrine, while others have excluded them. This Section analyzes how inattention to the doctrine's basic concepts has engendered this split in the lower courts.

\section{A. Supreme Court Formulations}

Each of the Supreme Court's act of state cases has declared that only public acts of the sovereign fall within the ambit of the doctrine. However, the Court has not explained this requirement. As a result, the Court has struggled increasingly over the basic question of how acts of state should be identified. In its most re-

${ }^{34}$ Most recently, in Kirkpatrick, Justice Scalia, writing for a unanimous Court, noted in dicta that if an "act of state" were at issue, the balancing test would apply. $110 \mathrm{~S} \mathrm{Ct} \mathrm{701,}$ 706-07 (1990).

${ }^{36}$ See, for example, Dellapenna, 35 Vill L Rev at 74-75 (cited in note 4). Dissatisfaction with the malleability of the Sabbatino test led to an attempted legislative overruling by the Hickenlooper Amendment, a late addition to the Foreign Assistance Act of 1964, Pub L No 88-633, §301(d), 78 Stat 1009, 1013, codified at 22 USC § 2370(e)(2) (1988). This effort failed due to extremely narrow and hostile judicial interpretation, which has essentially limited the Amendment's application to in rem proceedings. See Hunt $v$ Coastal States Gas Producing Co., 583 SW2d 322, 326 (Tex 1979) (amendment does not apply to contractual rights). 
cent decision on the issue, the Court rightly decided to clarify the doctrine by circumscribing its application..$^{36}$ But, in so doing, the Court remained silent on the question of whether abuses of sovereign authority are public acts, again leaving lower courts uncertain about this fundamental issue. This subsection presents the history of Supreme Court jurisprudence on the public act question.

\section{Early cases.}

Doctrinal uncertainty began with the Court's first act of state decision. The brief Underhill holding-that U.S. courts may not sit in judgment of the public acts of a foreign government undertaken within its own territory ${ }^{37}$-is remarkable for its ambiguity. Yet, one must resort to Underhill for its articulation of the public act requirement. Critical to the Court's identification of Hernandez's acts as acts of state was the fact that the alleged imprisonment was not "actuated by malice or any personal or private motive." ${ }^{38}$ Thus, at the doctrine's inception, actions by foreign officials undertaken solely for private gain were excluded from its scope. The decision was silent, however, as to what criteria should be considered in determining that personal motives were absent.

The cases following Underhill offered little opportunity to elaborate upon the public act requirement. Each involved an official decree expressing public concerns and, putting aside the question of recognition of the government, therefore constituted a sovereign act. ${ }^{39}$ Sabbatino similarly involved a formal expropriation, and while it mandated a novel balancing approach for future cases, it shed no new light on the definition of "public act."

2. Declining to resolve the question.

In Alfred Dunhill of London, Inc. $v$ Republic of Cuba, ${ }^{40}$ the Court failed to reach a majority on the question of how acts of state should be identified. Offering very different rationales, five Justices ultimately agreed that it was not an act of state for a private entity acting on the Cuban government's behalf to refuse to

${ }^{36}$ Kirkpatrick, $110 \mathrm{~S} \mathrm{Ct}$ at 704-05.

37 Underhill, 168 US at 252.

${ }^{38}$ Id at 254.

39 See, for example, Oetjen, 246 US 297; Ricaud, 246 US 304 (property seized by Mexican revolutionary forces and sold to private parties who brought the property to the United States); United States v Belmont, 301 US 324 (1937); United States v Pink, 315 US 203 (1942) (nationalization of property by the Soviet government).

10 425 US 682 (1976). 
return funds that Dunhill had mistakenly paid for cigars sold to it by expropriated Cuban businesses. The crux of the dispute concerned sums owed by importers for cigars shipped before the nationalization, but for which payment had subsequently been made to the Cuban government. The lower court decided that Cuba was legally obligated to return part of these payments, but Cuba refused. The question, therefore, was whether the Cuban agent's repudiation of this obligation constituted an act of state.

The Court did not settle on a majority view of what constitutes a public act. Rather, it jumped ahead to the question of whether some "acts of state" should nevertheless be exempted from the doctrine. Four Justices endorsed a commercial act exception to the doctrine, reasoning that sovereigns engaging in commercial activity are engaged in private or commercial acts. ${ }^{41} \mathrm{Com}$ mercial acts, which the Court termed "private," are no less expressions of the sovereign will simply because they concern matters of commerce rather than public policy. The conduct is still pursuant to sovereign authority. Yet the plurality excluded them from the doctrine because they are private, in the sense that private citizens undertake commercial activities as well. The plurality decided that commercial acts are not public, but failed to explain the meaning of "public." 42 Therefore, Dunhill addressed the issue of whether acts found to be sovereign may fall outside the scope of the doctrine, while leaving open the threshold question of what qualifies as a public act.

In the Court's most recent act of state decision, W. S. Kirkpatrick \& Co., Inc. $v$ Environmental Tectonics Corp., Int'l, ${ }^{43}$ the alleged sovereign act was the receipt of bribes by a Nigerian offcial. The parties were U.S. corporations that had submitted bids for a Nigerian military procurement contract. Environmental Tectonics, the unsuccessful bidder, sued Kirkpatrick, the successful bidder, alleging payment and receipt of bribes in connection with the award of the contract. Kirkpatrick asserted the act of state de-

"Id at 695. On the other hand, "non-sovereign" denotes unauthorized, unratified, or privately motivated actions by foreign officials. As such, these actions cannot be expressions of the sovereign will, and therefore can never be deemed sovereign acts, regardless of whether they are "commercial" or "public" in nature. Therefore, the public/non-sovereign distinction does not affect the issue of whether an act is commercial.

42 Justice Stevens disagreed. By joining in Sections I and II of the plurality opinion, he apparently looked only to whether the commercial act was done by someone with authority to act on behalf of the state, regardless of whether there was actual authority for the conduct at issue. Id at 715 .

43 110 S Ct 701. Kirkpatrick is the first Supreme Court act of state decision since Dunhill in 1976. 
fense, on the theory that the doctrine barred inquiry into the motives of the Nigerian official in awarding the contract.4

The parties argued extensively over the definition of the public act requirement, yet the Court declined to resolve the issue. The plaintiff argued that the conduct was not the public act of a sovereign because the criminal act of receiving bribes was not an exercise of sovereign power. ${ }^{45}$ Kirkpatrick went to great lengths to avoid characterizing the relevant act as the acceptance of the bribe, preferring the broader characterization of the act as the award of a military procurement contract. ${ }^{46}$ The Court noted that the lower court opinions found the act to rise to the level of a public act of state, but made no finding of its own. ${ }^{47}$ Instead, the Court adopted a new threshold test, holding that the doctrine is inapplicable unless the validity of the act is directly challenged: "[a]ct of state issues only arise when a court must decide-that is, when the outcome of the case turns upon-the effect of official action by a foreign sovereign." 48 The Court was not compelled to decide the validity of the act because in order for the plaintiff to prevail on its RICO and Robinson-Patman claims, it only needed to show that the bribery occurred. Rather than directly challenging the legality of official acts, then, the claim required only the imputation of improper motives, that is, finding the acceptance of a bribe. Because the validity of the acceptance of the bribe was not dispositive, the threshold test was not met on the facts of the case. The Court thereby skirted the public act issue.

44 Id at 703.

15 Brief for Environmental Tectonics Corp., Kirkpatrick v Environmental Tectonics Corp., Int'l, No 87-2066 at 24-27, citing Marcos, 806 F2d at 358-60 (2d Cir 1986); and Jimenez, 311 F2d at 557-58. The United States as Amicus Curiae also advanced this argument, as explained in Section III. Brief for the United States as Amicus Curiae, Kirkpatrick, No 87-2066, at 39-40.

46 Brief for W.S. Kirkpatrick \& Co., Inc., et al, Kirkpatrick, No 87-2066 at 28-29; Reply Brief for W.S. Kirkpatrick \& Co., Inc., et al, Kirkpatrick, No 87-2066 at 3-6. Courts arguably could look to the gravamen of the complaint to resolve this question as to which act is the act at issue. See Callejo v Bancomer, S.A., 764 F2d 1101 (5th Cir 1985). However, this standard ultimately proves indeterminate. Complainants simply characterize the events as best suits their purposes. In cases such as Kirkpatrick, courts could reasonably adopt either the broad or the narrow view of the conduct. On a motion to dismiss, of course, the court will adopt the nonmoving party's characterization.

$67110 \mathrm{~S} \mathrm{Ct}$ at 703.

48 Id at 705 (emphasis in original). Because "legality" is generally understood to refer to legality under local (here, Nigerian) law, courts use the term "validity" to denote legality under local U. S. and international law. See Restatement (Third) of the Foreign Relations Law of the United States $\$ 443$ comment d (1987). 
The Kirkpatrick result, allowing adjudication of the claim on the facts of the case, is difficult to fault. But the rule the Court announced falls short of what is needed to lend coherence to the doctrine. The fundamental shortcoming of the new rule is that the Court circumscribed the flexibility of the Sabbatino balancing test without clarifying how the test should be applied in the next case in which the threshold is met. A variation on the facts of Kirkpatrick reveals this problem. If Environmental Tectonics had impleaded the Nigerian official who accepted the bribe, the Court's threshold test would have been met because, in adjudicating a direct claim against a government official, the Court would have been called upon to determine whether the act was valid under Nigerian, U.S., and international law. At this point, the Court's characterization of the test as a factual predicate would fail; to decide whether the validity of an act of state is at issue, litigants must have some idea of what conduct constitutes an act of state. The Court's rationale in Kirkpatrick, by sidestepping this issue, only delays resolution of the substantive debate over the public act requirement.

Thus, the Court has said little about what constitutes a public act, and much less about what analytical apparatus should be used to determine whether one exists. As a result, it is not surprising that Dunhill, for example, is cited by both critics and supporters of the view that non-sovereign acts should be excluded from the definition of public act. ${ }^{48}$

\section{B. Lower Court Applications}

Because of the Supreme Court's lack of guidance, lower courts have disagreed over the question of how acts of state ought to be identified. Few courts have undertaken a substantive threshold inquiry into whether the alleged act is a public act of the sovereign. Courts that have scrutinized the conduct at the threshold have failed to justify their analyses and results by reference to the doctrine's core purposes. This Section analyzes judicial treatment of the issue, which may be divided into two basic categories: the expansive view and the restrictive view. ${ }^{50}$

19 Contrast Marcos, 818 F2d at 1485 (Dunhill supports inclusion of official corruption within the scope of the doctrine), with Galu v Swissair, 873 F2d 650, 653 (2d Cir 1989) (Dunhill supports exclusion of unratified acts of government officials from the doctrine).

${ }^{\text {so }}$ The use of the term "restrictive" here is not intended to correspond precisely to the restrictive theory of sovereign immunity. Although the two are conceptually similar in that they both distinguish between different types of acts by government officials, they do so toward different ends. 
1. The expansive view.

Several courts have interpreted "public act" expansively to include non-sovereign conduct by government officials. This expansive approach has resulted in broader application of the doctrine and therefore less frequent adjudication. The rationales in support of this rule have been sparse, apart from a general concern that the doctrine's scope of operation be as broad as possible. Judges' adherence to this view may flow less from a particular substantive theory of the doctrine than from a presumption in favor of diplomatic resolution of disputes even lightly touching on foreign sovereign affairs.

The earliest federal appellate court decision to endorse the expansive theory, Banco de Espana v Federal Reserve Bank, explicitly accepted the notion that acts illegal under the foreign country's laws can qualify as public acts. ${ }^{51}$ The act at issue was an illegal secret agreement between a Spanish official and the U.S. for the sale of silver. The Bank of Spain sued the Federal Reserve Bank to recover the silver. The district court presumed that the agreement constituted a valid government act and concluded that the Bank of Spain was not entitled to the silver. ${ }^{52}$

On appeal, the Bank of Spain disputed the presumption on the ground that the agreement was unauthorized and therefore not a public act of the Spanish government. The Second Circuit rejected the Bank's argument and applied the act of state doctrine. In so doing, the court explicitly eschewed the distinction between authorized and unauthorized conduct in identifying acts of state: " [b]y a 'governmental act' is meant no more than a step physically taken by persons capable of exercising the sovereign authority of the foreign nation." "B3 Under this view, any act by any foreign official undertaken within the scope of governmental power may be shielded by the doctrine.

A Ninth Circuit panel also voiced its support for this expansive view of public acts in Republic of Philippines $v$ Marcos, ${ }^{54}$ before being reversed en banc. The Republic alleged that Marcos engaged in a RICO enterprise of conspiracy, fraud, and conversion, among other wrongs. Marcos asserted the act of state defense on the ground that adjudication would require the court to pass on

s1 114 F2d 438, 444 (2d Cir 1940).

62 Id at 441.

ss Id at 444 .

618 F2d 1473. The panel decision is not law, of course, but it aptly illustrates the controversy surrounding this issue. 
the legality of the alleged acts. A majority of the original panel rejected the argument that Marcos's acts were privately motivated and therefore not governmental, citing Dunhill:

[Gaining] access to the public monies by statute, decree, resolution, order, or some other 'governmental act' as president [would be an act of state].

...

It would greatly weaken the act of state doctrine if parties could put in question the validity of official governmental acts simply by attacking the motives of the government officials who undertake them. ${ }^{.5}$

In addition to these explicit holdings, courts that refuse to adopt a corruption exception to the doctrine also implicitly support the inclusion of non-sovereign acts in the definition of public act. $^{56}$ In Clayco Petroleum Corp. ${ }^{57}$ for example, the plaintiff alleged that Armand Hammer bribed the sheik of Umm Al Qaywayn to obtain an oil concession originally promised to Clayco. The court dismissed the suit on the theory that "embarrassment would result from adjudication" whether the act was properly or improperly motivated..$^{88} \mathrm{By}$ refusing to exempt corrupt acts, the court effectively decided that the acceptance of the bribe was a public act. $^{58}$

${ }^{B S}$ Id at 1485 . In a dissenting opinion that ultimately carried the day in the court's reversal en banc, Judge Nelson countered with a refusal to "adhere to the position that the alleged acts of receiving bribes, plundering the treasury, and extortion are the result of 'complex political and policy choices.' " Id at 1493 (quoting majority opinion, 818 F2d at 1485).

${ }^{B B}$ Some courts have recognized a corruption exception, reasoning that Congress's enactment of the Foreign Corrupt Practices Act, 15 USC §§ 78dd-1, 78dd-2 (1988) ("FCPA"), evidences a policy against foreign corruption intended to be vindicated in private litigation. See, for example, Sage International, Ltd., $534 \mathrm{~F}$ Supp at $910 \mathrm{n} 26$. Other courts have questioned or rejected the exception, refusing to disturb the Sabbatino balancing test by carving out an exception, and arguing that the FCPA was not intended to be vindicated in private litigation. See, for example, Lamb v Philip Morris, Inc., 915 F2d 1028, 1037-45 (6th Cir 1990) (no implied private right of action under FCPA); Occidental Petroleum Corp. $v$ Buttes Gas \& Oil Co., 331 F Supp 92 (C D Cal 1971), aff'd, 461 F2d 1261 (9th Cir 1972).

${ }^{87} 712$ F2d 404 (9th Cir 1983) (per curiam).

ss The court concluded, "The very existence of plaintiffs' claim depends upon establishing that the motivation for the sovereign act was bribery, thus embarrassment would result from adjudication." Id at 407.

${ }^{58}$ See also O.N.E. Shipping Ltd., 830 F2d at 452-53; West v Multibanco Comermex, S.A., 807 F2d 820, 828-29 n 7 (9th Cir 1987); Compania de Gas de Nuevo Laredo v Entex, 686 F2d 322, 326 (5th Cir 1982) (all refusing to endorse the corruption exception). 
2. The restrictive view.

On several occasions, federal appellate courts have explicitly concluded that acts in contravention or in excess of authority as well as acts done purely for private gain, cannot be public acts of the sovereign. This restrictive view requires a more exacting scrutiny of the acts in question to determine whether the official was actually authorized to bind the state. However, much like the decisions endorsing the expansive view, these opinions fail to support their results with a coherent vision of the doctrine.

In Jimenez $v$ Aristeguieta, ${ }^{60}$ the former dictator of Venezuela sought habeas corpus relief from an extradition order. The district court found his financial dealings criminal within the meaning of the relevant extradition treaty and ordered the former dictator to be extradited. ${ }^{61}$ The dictator argued to the Fifth Circuit that the act of state doctrine should nullify the district court's finding that his acts were criminal. The appellate court rejected his argument, deciding that "[i]t is only when officials having sovereign authority act in an official capacity that the act of state doctrine applies." 62 The court emphasized that financial crimes such as embezzlement, fraud, and receipt of unlawfully obtained money or securities were not public acts of Venezuela where such acts were done for the dictator's private financial benefit. ${ }^{63}$

Likewise, in Republic of Philippines $v$ Marcos, ${ }^{64}$ the Second Circuit opined that privately motivated acts of government officials were outside the doctrine's reach. The court was presented with an appeal of an injunction affecting title to real estate owned by former Philippine President Marcos. Marcos acquired the land, located in the U.S., with funds allegedly received from bribes and kickbacks. ${ }^{65}$ As in Jimenez, identification of the act of state turned on a fact-intensive scrutiny of the alleged acts to determine whether they were public acts that could be shielded from judicial

-0 311 F2d 547 (5th Cir 1962).

-1 Id at 557-58. The fact that the source of law was a treaty, rather than a local law, does not distinguish this case from those that adopt the expansive view. Jimenez argued that even assuming his acts were unlawful, regardless of the source of law, the act of state doctrine should apply, because the conduct was done in exercise or under color of his sovereign authority. Id, citing Underhill, 168 US 250.

${ }^{82}$ Id at 557.

os Id. The court distinguished the facts of Underhill, in which Chief Justice Fuller had explicitly relied on the lack of private motive as a basis for applying the doctrine. See $U n$ derhill, $168 \mathrm{US}$ at 254.

ot 806 F2d 344 (2d Cir 1986).

os Id at 346-48. Note that these facts are, for purposes of this discussion, virtually identical to those in the Ninth Circuit's Marcos case. See text at notes 54-55. 
examination, or whether they were "purely private acts." court remanded the case, instructing the defendants to come forward with evidence that Marcos obtained his wealth "through official expropriation decrees or public monopolies."67 The court said that if Marcos had acquired his wealth by those means, his activities would be considered "public." The Marcos and Jimenez courts therefore concluded that where foreign officials allegedly contravene their authority, or act purely for private gain, they cannot be said to be acting on behalf of the state. ${ }^{68}$ In the Ninth Circuit's companion case to the Second Circuit Marcos litigation, an en banc panel came to the same conclusion..$^{69}$

This restrictive view of public act has also been applied to prevent application of the doctrine to human rights violations. In Forti v Suarez-Mason, ${ }^{70}$ Argentine citizens brought suit against a former Argentine general under the Alien Tort Statute ${ }^{71}$ (§ 1350) for torture. The court held that the act of state doctrine did not bar adjudication:

[F]or purposes of $\S 1350$ a plaintiff must allege "official" (as opposed to private) action-but this is not necessarily the

so Id at 358.

${ }^{87}$ Id at 359-60. Thus the court uses the restrictive view to require a stronger factual showing. See Ramirez de Arellano v Weinberger, 745 F2d 1500, 1534 (DC Cir 1984) (en banc) (movant must make "factual showing that an act of state has occurred, coupled with a legal showing that no bar to the doctrine is applicable under the factual circumstances"), vacated on other grounds, 471 US 1113 (1985).

Moreover, the Second Circuit's proffered examples of public acts suggest that the district court should look for a higher degree of formality than that required by Jimenez.

${ }^{88}$ See also Sharon v Time, Inc., 599 F Supp 538, 544 (S D NY 1984) (act of state doctrine not applied to Israeli defense minister's alleged statements concerning massacres in Lebanon, because doctrine was "limited to laws, decrees, decisions, seizures and other officially authorized 'public acts' '); Galu, 873 F2d at 654 (U.S. citizen expelled from Switzerland and forcibly transported to U.S.; remanded to determine whether action "had been ordered in the exercise of the sovereign authority of Switzerland," or was "simply an ad hoc decision of local police officers"). See discussion of Galu in text at notes 115-18.

${ }^{69}$ Marcos, 862 F2d 1355 (doctrine does not apply to corrupt acts undertaken for private purposes). See also DeRoburt v Gannett Co., Inc., 733 F2d 701 (9th Cir 1984) (doctrine does not shield privately motivated secret and illegal loans by former President of Nauru).

${ }^{70} 672$ F Supp 1531 (N D Cal 1987).

${ }^{21} 28$ USC $\$ 1350$ (1988). The statute grants district courts original jurisdiction over "any civil action by an alien for a tort only, committed in violation of the law of nations or a treaty of the United States." The act in question must, for jurisdictional purposes, be "offcial" to qualify as a violation of the law of nations. But because sovereign immunity shields "officially authorized" torture, once the jurisdictional requirements are met the plaintiff must proceed against the alleged torturer in her private capacity. See Filartiga v PenaIrala, 630 F2d 876, 890 (2d Cir 1980), citing Ex parte Young, 403 US 388 (1971). For a more detailed analysis of $\$ 1350$, see Anne-Marie Burley, The Alien Tort Statute: A Badge of Honor, 83 Am J Intl L 461, 488-93 (1989). 
governmental and public action contemplated by the act of state doctrine. . . . Indeed, since violations of the law of nations virtually all involve acts practiced ... by states, defendant's argument would in effect preclude litigation under $\S 1350$ for 'tort[s] . . . committed in violation of the law of nations. ${ }^{\text {'2 }}$

Because the defendant failed to identify an act of state, the court found it unnecessary to analyze the Sabbatino factors. ${ }^{73}$ The suit proceeded on the fiction that the official acted in his private capacity.

In sum, the public act issue has become a pivotal question in recent act of state cases, yet courts have reached divergent results, and the varying use of exceptions only confuses the various applications. The next section outlines a resolution.

\section{A Proposed Definition of Public Acts}

Much of the controversy in act of state cases turns on the lack of a well-reasoned definition of "public act." This Section proposes and justifies a restrictive definition. The first subsection presents the proposed definition, and the second subsection outlines the rationales behind a restrictive approach. The third subsection sets out specific criteria for determining when an act fits the definition. Finally, the Comment applies the definition to the facts of a case to illustrate how the definition works.

\section{A. The Proposed Definition}

Any elaboration of the public act requirement must reconcile the prerogatives of foreign sovereigns (comity), the Executive's role in conducting foreign relations (separation of powers), and the integrity of domestic courts (justiciability). To satisfy this broad set of concerns, courts might interpret the act of state doctrine to cover all conduct of a foreign official regardless of its form or the official's underlying motive. However, the breadth of the doctrine's purposes does not mandate an unlimited scope of application. In fact, fulfillment of the doctrine's goals may be best served by a more limited application, because when judges view the doctrine as overly broad, they hesitate to apply it. The underlying purposes will be served more effectively if precise criteria are established for

\footnotetext{
72 Forti, 672 F Supp at 1546 (citation omitted).

${ }^{73}$ Id at 1546 n 9, citing Ramirez de Arellano, 745 F2d at 1534.
} 
designating "public acts." Rather than using comity, separation of powers, and justiciability concerns to expand application of the Sabbatino balancing test, courts can and should use these rationales to narrow it.

Proceeding from this approach to the doctrine, a public act is best defined as encompassing only the authorized or ratified acts of government officials undertaken for public purposes. The definition should exclude unauthorized, unratified, or privately motivated conduct, even if undertaken under color of law or within the scope of official duties. ${ }^{74}$ It should exclude, in short, "non-sovereign" acts.

This clear, limited category of "public acts" would not only fulfill the doctrine's goals, but it would also facilitate application and acceptance of the balancing test, thereby eliminating much of the controversy that led to scattered exceptions. Some commentators frame the issue of excluding non-sovereign acts in terms of whether a private acts exception should be carved out of the doctrine. ${ }^{75}$ To carve exceptions out of the doctrine before fully articulating a standard for the scope of its application is a weak approach. The better view is to resolve the question of identifying acts of state in terms of what the doctrine is, rather than what it is not.

\section{B. Rationales Guiding the Proposed Approach}

As Section I of this Comment demonstrates, the act of state doctrine encompasses three policy concerns: comity, separation of powers, and justiciability. These purposes support the exclusion of non-sovereign acts adopted in the proposed definition. In addition, several independent rationales for this approach address other important concerns, particularly in the realm of international human rights.

\section{Comity.}

Comity is a principle, rooted in public international law, of respect for or courtesy toward foreign sovereigns. ${ }^{76}$ At its origin in

${ }^{74}$ This approach is consistent in result with the restrictive view of public acts elaborated in Section II.B.2. While those decisions adopted this basic interpretation, no court has defended it in terms of an overall conception of the doctrine's framework and purposes.

${ }_{75}$ See Restatement (Third) of the Foreign Relations Law of the United States $\$ 443$ reporter's note 3 (1987).

${ }^{76}$ Id at $\$ 403$ reporter's note 2; Brownlie, Principles of Public International Law at 31 (cited in note 14); Hessel E. Yntema, The Comity Doctrine, 65 Mich L Rev 9 (1966). See Section I.A.I. 
Underhill, the act of state doctrine rested upon this concern for harmony in the international system. ${ }^{77}$ Generally speaking, comity requires a court to recognize the foreign government's acts or laws. In the act of state context, assuming that the doctrine operates as a rule of abstention, this principle of recognition ordinarily entails a refusal by the court to decide the issue at hand out of respect for the sovereign. ${ }^{78}$

The proposed definition of public act to exclude non-sovereign acts comports with the comity principle. This Comment's definition excludes acts that the sovereign would not claim as its own. Therefore, comity would not mandate recognition of those nonsovereign acts. For the same reason, in circumstances involving non-sovereign acts, a court actually would accord greater respect to the foreign government by adjudicating the dispute than by designating the act an act of state. When a suit involves renegade foreign officials or officials whose conduct the sovereign approves but seeks to disclaim in the world community, a more serious affront to the sovereign would result from imputing the officials' acts to the sovereign-by deeming them public acts-than would result from allowing parties to proceed in court. Moreover, comity has never been viewed as an absolute obligation. It requires that courts recognize the acts of other nations only to the extent that domestic interests are not prejudiced. ${ }^{79}$ Therefore, even apart from the question of an act's status as a non-sovereign act, international law does not impose a strict duty on U.S. courts to apply the comity principle whenever foreign government actors are involved. The principle of comity, therefore, cuts in favor of a restrictive definition of public acts.

\section{Separation of powers.}

In the act of state context, courts have interpreted separation of powers to require that they should avoid embarassing the Executive in its foreign policy efforts. ${ }^{80}$ The embarrassment results

77 Underhill, 168 US at 252.

78 In Oetjen, 246 US 297, the Court decided that in circumstances meriting application of the doctrine, an examination of the validity of the foreign sovereign's act would " imperil the amicable relations between governments and vex the peace of nations." " 246 US at 303 (citation omitted).

79 See Hilton v Guyot, 159 US 113, 164 (1895) (comity is "the recognition which one nation allows within its territory to the ... acts of another nation, having due regard both to international duty and convenience, and to the rights of its own citizens . . ..").

${ }^{\text {so }}$ See Sabbatino, 376 US at 433. See Section I.A.2. 
from inconsistent pronouncements from the Executive and Judiciary branches about the particular foreign sovereign conduct at issue. ${ }^{81}$ Therefore, courts tend to apply the act of state doctrine when there is a danger that a judgment of the court will conflict with the Executive's foreign policy efforts.

To meet this concern, the act of state doctrine should seek to protect from judicial scrutiny those issues that lie at the heart of diplomatic affairs. In general, the conduct of diplomacy among nations focuses on the properly motivated "governmental" acts of sovereigns. Unauthorized acts of foreign officials, which the sovereign would not claim as its own, lurk at the periphery of foreign affairs, and therefore present a far weaker threat to the ordinary conduct of foreign relations. Therefore, the non-applicability of the doctrine to unauthorized or unratified acts satisfies separation of powers concerns by preserving for the Executive the core issues it confronts.

The current Administration recently offered a compelling argument in favor of the view that exclusion of non-sovereign acts gives full expression to separation of powers concerns. In an amicus brief in Kirkpatrick, the Solicitor General and the Legal Adviser of the State Department argued against applying the doctrine, thus endorsing the restrictive view of "public acts."82 They distinguished the allegedly corrupt personal motivations of individuals acting on behalf of the Nigerian government as not being official purposes of the Nigerian government in awarding the contract. ${ }^{83}$ The policy significance of this distinction, they contended, was that "on balance and especially in the long run, [] the foreign policy interests of the United States would be furthered by rooting out efforts by its nationals to corrupt" foreign governmental processes, and that "the government of the other nation also may have a strong interest in exposing and expunging corruption in its own affairs ... or may be content to let matters unfold as they will in United States courts." 84 A case such as Kirkpatrick might embarrass members of the foreign government, thereby potentially "embarrassing" the U.S. in its conduct of foreign relations. But the

81 Id at $432-33$

82 Brief for the United States as Amicus Curiae Supporting Respondent, Kirkpatrick, No $87-2066$, at $39-40$.

${ }^{83}$ Id at 39, citing Ex parte Young, 209 US 123 (1908). Compare Banco de Espana $v$ Federal Reserve Bank of New York, 114 F2d 438, 444 (3d Cir 1940), in which the Second Circuit rejected this analogy.

84 Brief for the United'States as Amicus Curiae Supporting Respondent, Kirkpatrick, No 87-2066, at 39, citing Marcos, 862 F2d 1355. 
amici argued that it posed much less of a threat to U.S. foreign relations concerns than an "affront to the sovereignty of the foreign nation itself." consistent with a limited definition, and in some ways reinforce the arguments in favor of it. ${ }^{86}$

\section{Justiciability.}

Courts honor justiciability concerns when they decide to abstain in cases involving foreign relations issues for which judicially manageable standards are unavailable. The issue of justiciability is related to, but conceptually distinct from, the separation of powers strand of the doctrine, because it embodies the judiciary's distinct need to preserve its own institutional integrity. ${ }^{87}$ Assuming that a suit against or involving a foreign official concerns unauthorized conduct that is illegal under either U.S., local, or a well-established rule of international law, little threat is posed to a court's institutional competency. The court is simply directed to apply "an agreed principle to circumstances of fact." ${ }^{\text {88 }}$ On the other hand, if the suit involves a hotly disputed issue of domestic or, more likely, international law, which embroils the court in ideological conflict, justiciability concerns rightly counsel against adjudication..$^{88}$

ss Brief for the United States as Amicus Curiae Supporting Respondent, Kirkpatrick, No $87-2066$, at 39 .

${ }^{88}$ Other jurisprudential safeguards exist to protect U.S. foreign policy interests and the integrity of U.S. courts in cases in which the restrictive approach might appear to threaten them. Head of state immunity, for instance, enables courts to immunize some private acts of high government officials still in power. See 1975 Dig US Prac Intl L 344-45 \& n 1 ("head of state performs important functions which should not be interfered with by the necessity of defending litigation in foreign countries"). If Marcos had remained in power during the pendency of the suits against him, he could have sought protection under this doctrine. Id (noting that Marcos had been granted head of state immunity in a libel action).

Where foreign officials can argue that local law required them to commit allegedly illegal acts, their conduct may also be shielded from judicial scrutiny by the foreign sovereign compulsion doctrine. Resting on comity concerns, this doctrine is fully consistent with the proposed definition. Both permit circumspect inquiry into a foreign official's motivations that Kirkpatrick allows. See Restatement (Third) of the Foreign Relations Law of the United States $\S 441$ (1987) ("In general, a state may not require a person ... to refrain from doing an act in another state that is required by the law of that state ...."). Thus far, however, courts have recognized the foreign sovereign compulsion defense only in the antitrust context. See, for example, Interamerican Refining Corp. v Texaco Maracaibo, Inc., 307 F Supp 1291 (D Del 1970).

${ }^{87}$ See Section I.A.3.

${ }^{88}$ Sabbatino, 376 US at 428-29. As the Sabbatino Court noted, there is a vast body of international law in which "consensus as to standards is greater and which do[es] not represent a battleground of conflicting ideologies." Id at $430 \mathrm{n}$ 34. Therefore, justiciability concerns do not "broadly foreclose[]" courts from ruling on international law claims. Id.

80 Such circumstances led to application of the doctrine in Sabbatino itself, where the Court decided that the ideological disagreement over expropriation was not amenable to 
Analysis of the decisions resolving claims based on "non-sovereign" conduct reveals that such cases have involved the types of governmental conduct for which legal standards are readily available, such as bribery, fraud, conversion, wrongful imprisonment, and torture. ${ }^{90}$ Such cases have not generally involved claims based on international law, which have been more susceptible to open disagreement. While suits involving non-sovereign' acts are often politically sensitive, they have not involved ideologically contestable issues such as the expropriation in Sabbatino. Defining the public act requirement as excluding such non-sovereign acts, therefore, will not ordinarily pose justiciability concerns, because most of the cases involving foreign officials will indeed involve matters that courts will have had experience in considering. ${ }^{91}$ A limited definition of public act better reflects the fact that lack of justiciability is a concern that comes into play in only a narrow range of cases.

\section{Additional rationales.}

The proposed rule has additional strengths that relate both to the doctrine's application and to broader jurisprudential concerns. This subsection explains how the proposed definition comports with existing act of state jurisprudence, promotes the international rule of law, and reinforces international human rights law.

suit. Id at $430 \&$ n $34,434-35$. See also Dunhill, 425 US at 703-04 \& n 16 (weaker justiciability concerns when non-governmental acts of sovereign at issue; much greater concerns in international commercial law).

so For a number of claims involving official corruption, international standards are available. See, for example, United Nations Draft Convention against Torture and Other Cruel, Inhuman, or Degrading Treatment or Punishment, Gen Assembly Res 39/46 (Dec 10, 1980), draft reprinted in 23 ILM 1027 (1984), substantial changes noted in 24 ILM 535 (1985). Where such standards are lacking, courts can simply apply the law of the foreign state. As the Brief for the Respondent in Kirkpatrick, at $30 \mathrm{n} 20$, points out: "Virtually every nation treats bribery of its officials as a crime," citing John T. Noonan, Jr., Bribes 702 (Macmillan, 1984); Lois Regent Driscoll, The Illegality of Bribery: Its Roots, Essence, and Universality, 14 Cap U L Rev 1, 13-38 (1984). "Even where such conduct is not criminal, it typically gives rise to civil liabilities." Id, citing Hans Henrik Lidgard, et al, A Survey of Commercial Agency 32, 66, 126, 216, 434-35, 480-81 (1984). See also Statute of the International Court of Justice, Art 38, I 1(c) (1945).

${ }^{91}$ Furthermore, in those cases turning on politically contestable matters, courts retain the option of dismissal under the political question doctrine, another pragmatic abstention device. Indeed, "[c]ases touching on the foreign relations of the United States make up the largest class of cases to which the political question doctrine has been applied." Michael J. Bazyler, Abolishing the Act of State Doctrine, 134 U Pa L Rev 325, 390 (1986), citing Baker v Carr, 369 US 186, 211-14 (1962); and Tel-Oren v Libyan Arab Republic, 726 F2d 774, 803 (DC Cir 1984). This option might be considered, for instance, in the unusual case in which the sovereign's laws do not prohibit acceptance of bribes by its officials. 
First, the proposed view is consistent with current Supreme Court act of state jurisprudence. It originates in Underhill, the first act of state decision by the Supreme Court. Furthermore, application of the proposed view does not intrude upon the $S a b b a$ tino framework. It respects the Sabbatino balancing test because it does not challenge the test's conceptual underpinnings, as exceptions do. That is, it does not alter or circumscribe the criteria that courts consider in the balancing process. The proposed definition instead limits the class of cases to which the test should properly be applied. Moreover, by endorsing a threshold requirement for applying the balancing test, it is consistent with Kirkpatrick. When the validity of some arguably governmental act is challenged-that is, the Kirkpatrick threshold is satisfied-courts may still hold that a public act is absent and decide not to adjudicate the case. ${ }^{92}$

Second, the proposed definition promotes the rule of law. By permitting adjudication of claims involving corrupt acts, it discourages U.S. corporations dealing with foreign officials from offering bribes and inducing other fraudulent conduct. It thus provides an incentive for U.S. nationals to comply with U.S. law. Excluding abuses of governmental authority also promotes compliance with international law more generally by allowing redress of injuries through the U.S. court system, which is more readily available and usually more reliable than the diplomatic process. Inclusion of unauthorized acts within the definition of public acts, on the other hand, encourages disregard for the international rule of law by allowing private parties to shield themselves from civil liability.

Third, the proposed definition of public act is more consistent with judicial interpretations of the Alien Tort Statute. ${ }^{93}$ Under $F i$ lartiga $v$ Pena-Irala, ${ }^{94}$ the statute authorizes private tort suits in U.S. district courts against former government officials in their individual capacity. Filartiga adopted the presumption, consistent with current conceptions of individual rights and responsibilities in international law, that torture cannot be authorized by any government unless the government is brash enough to admit that torture

92 Given this Comment's analysis, however, the more logical approach would be to begin with the definitional "public act" analysis before applying the motivation/validity standard to the conduct in question.

9s 28 USC § 1350 . See note 71.

* 630 F2d 876 (2d Cir 1980). 
is not illegal under its own laws. ${ }^{90}$ According to $\S 1350$ jurisprudence, the narrow category of tortious acts that fall within the statute are not sovereign acts. Non-application of the act of state doctrine would therefore be consistent with $\S 1350$.

Despite this conceptual consistency, judges hostile to Filartiga have suggested that the act of state doctrine might well be used to avoid deciding cases brought under $\S 1350 .{ }^{96}$ When courts take an expansive view of public acts, the doctrine can be used to bar adjudication of torture claims, clearly recognized under international law, on the theory that torture is an act undertaken within the scope of official duties. This result is incongruous with the fact that courts at the same time could decline to apply the doctrine to bribery cases, under the Kirkpatrick motivation/validity distinction.

A narrow definition of public act, on the other hand, removes the act of state hurdle in Alien Tort cases and would make these claims easier to litigate in U.S. courts. ${ }^{97}$ The proposed definition is therefore more consistent with $\S 1350$ and with current conceptions of individual responsibility in international law. ${ }^{98}$ Not surprisingly, many scholars support non-application of the doctrine in the Alient Tort context. ${ }^{90}$ Thus, the proposed definition fits within and helps clarify the existing act of state framework. It reflects the

8s See Burley, 83 Am J Intl L at 491 (cited in note 71).

${ }^{96}$ See, for example, Tel-Oren, 726 F2d at 803, 812-16 (Bork concurring) (act of state doctrine might apply to bar $\$ 1350$ claim, which only encompasses violations of the "law of nations" extant in 1789).

${ }^{97}$ Indeed, the Forti court suggested, non-application of the doctrine to $\S 1350$ claims is vital to their survival. Forti v Suarez-Mason, 672 F Supp 1531, 1546 (N D Cal 1987).

s International law has significantly expanded since 1789 , particularly with respect to protections from government action afforded to individuals. See Restatement (Third) of the Foreign Relations Law of the United States \$§ 701-713 (1987). Indeed, "the cornerstone of twentieth-century human rights law is the explicit recognition that the treatment by a state of its own citizens is a legitimate matter of international concern and thus of import to its fellow states." Burley, $83 \mathrm{Am}$ J Intl L at 490 (cited in note 71) (citing relevant international agreements). See also M.W. Janis, Individuals as Subjects of International Law, 17 Cornell Intl L J 61 (1984); Louis Henkin, International Human Rights as "Rights", 1 Cardozo L Rev 425 (1979); Rosalyn Higgins, Conceptual Thinking about the Individual in International Law, 24 NY L Sch L Rev 11 (1978). This contemporary theory, coupled with the manifest congressional intent to provide redress in U.S. courts under $\S 1350$, effectively counters the argument that human rights suits present the most compelling circumstances for application of the act of state doctrine.

89 For arguments couched in terms of a "human rights exception" to the act of state doctrine, see Jeffrey M. Blum and Ralph G. Steinhardt, Federal Jurisdiction over International Human Rights Claims: The Alien Tort Claims Act after Filartiga v. Pena-Irala, 22 Harv Intl L J 53, 108-09 (1981); Burley, 83 Am J Intl L at 491 n 133 (cited in note 71); Chow, 62 Wash L Rev at 445-46 (cited in note 26); see also Restatement (Third) of the Foreign Relations Law of the United States $\$ 443$, comment c (1987). 
policies that animate the doctrine. Furthermore, it clearly protects claimants under $\S 1350$ from act of state defenses, thereby preserving an important class of cases-suits for human rights violations brought by aliens in U.S. courts.

\section{Criteria for Application}

Devising specific criteria for applying the "public act" label is among the most challenging tasks courts face in the act of state context. ${ }^{100}$ The difficulty results largely from the great variety of cases in which litigants invoke the doctrine. While some cases have isolated factors to consider in identifying acts of state, ${ }^{101}$ none has presented a catalogue of factors nor a technique for applying them. ${ }^{102}$ This Section provides a set of relevant factors and a method for applying the proposed public act standard.

Four specific criteria, derived from the realities of agents' conduct, can be articulated for narrowing the definition of public act to exclude non-sovereign acts. The relevant factors are (1) the authority under which an official acts; (2) the level of formality of the act; (3) the stage in the governmental process at which the official acts; and (4) the official's position. In light of the various ways a sovereign may act, no single criterion is determinative. But considering these factors together, courts can exclude non-sovereign acts from the scope of the doctrine with relative ease.

Importantly, the proposed method for identifying a public act questions only the status of the act. That is, it seeks to determine whether the act is a sovereign act at all. The approach does not contemplate substantive scrutiny of the conduct at issue. If excluding non-sovereign acts required a U.S. court to examine the local legality of the act, the definition would run afoul of the central goal of the doctrine itself: to avoid judicial inquiry into the validity of the sovereign act. ${ }^{103}$ As a threshold evaluation of the evidence of the official's motivation in undertaking the act, or the sovereign's approval of that act, before applying the "act of state" label, the exclusion of "non-sovereign" conduct steers clear of this dilemma. Such inquiry does not investigate the conduct's local legality; it

${ }^{100}$ See Dellapenna, 35 Vill L Rev at 4-5 (cited in note 4).

101 See, for example, Sharon, $599 \mathrm{~F}$ Supp at 544 (formality requirement).

${ }^{102}$ Many courts appear simply to consider all government agents' acts to be acts of state. See, for example, Guinto v Marcos, 654 F Supp 276, 280 (S D Cal 1986) (no definitional inquiry).

${ }^{103}$ Such substantive scrutiny would render the doctrine hopelessly circular. A court would determine whether the act was a public act meriting protection from determination of substantive local legality by asking whether the act was locally legal. 
merely determines its status. ${ }^{104}$ Each factor in the determination of that status is considered below.

\section{Authority.}

To decide whether official conduct constitutes a public act, courts should first decide whether the alleged conduct is authorized. If an act is not undertaken pursuant to some delegation of authority, or sanctioned by some lawful or customary process, courts should not deem it to be a sovereign act. Conduct motivated by private gain, such as acceptance of bribes or kickbacks, should be deemed conclusively unauthorized. ${ }^{105}$ Although this public/private distinction may be characterized as indeterminate, in practice it has not proved difficult to administer. ${ }^{106}$

Non-sovereign acts may also take forms other than privately motivated wrongdoing. Even if the act is deemed publicly motivated, courts must nevertheless decide whether the act exceeds or contravenes the official's authority to perform governmental duties. Courts should look to whether government approval occurred through some lawful or customary process. To prove that the official did not exceed or contravene sovereign authority, the party asserting the act of state defense must come forward with factual evidence of a continuous "chain of command" sanctioning the act in question. ${ }^{107}$ Post hoc ratification may also function as an indicator of sovereign approval. ${ }^{108}$ However, courts must scrutinize evidence of ratification carefully, to prevent the foreign government from ratifying the act merely to protect it from scrutiny in U.S.

104 Again, this approach is consistent with the factual burden of proof courts impose upon litigants asserting the act of state defense. Ramirez de Arellano, 745 F2d at 1534.

${ }_{108}$ As Section II illustrates, some courts have scrutinized sovereign agents' conduct to decide whether it was motivated by personal gain. Whether adopting the restrictive view or applying the corruption exception, courts have regularly required movants to come forward with evidence regarding the official's motivation. See, for example, Marcos, 862 F2d at 1361. The Supreme Court's adoption of the motivation/validity threshold test in Kirkpatrick also signifies approval of this factual inquiry.

${ }^{108}$ Distinguishing among various types of allegedly sovereign acts also underlies the theory of restrictive sovereign immunity, enshrined by Congress in the Foreign Sovereign Immunities Act, 28 USC $\$ \S 1602-1611$ (1982). See, for example, Texas Trading \& Milling Corp. v Federal Republic of Nigeria, 647 F2d 300, 316 \& n 38 (2d Cir 1981). This is not to suggest that the same analysis should be undertaken for act of state and sovereign immunity purposes. It merely suggests that arguments against the administrability of the proposed approach are unavailing.

${ }_{107}$ Galu, 873 F2d 650.

${ }^{308}$ See Filartiga, 630 F2d at 889 (doubting whether unratified acts should be characterized as acts of state). 
courts. The standard, again, should be whether the sovereign ratified the conduct according to some lawful or customary process.

\section{Formality.}

The second factor courts should consider is the degree of formality of the act. An expression of the sovereign will ordinarily takes the form of a "[s]tatute, decree, order, or resolution . . . because duly constituted governments generally act through formal means." ${ }^{109}$ In the usual circumstances, such formality will function as a helpful indicator of authorization, governmental purpose, or both. For instance, if a government leader issues an expropriation decree, the decree should be shielded from judicial scrutiny unless it is privately motivated.

A lack of formality should not be dispositive, however. ${ }^{110}$ The function that formality serves as a proxy for authorization is unnecessary where, for instance, a high-ranking government official makes an unwritten policy statement. In such cases, authorization may be presumed. Indeed, even at the doctrine's inception, formality was not required: the imprisonment in Underhill was not mandated by a formal statement, yet it received act of state protection. ${ }^{111}$ In addition, if the conduct in question involves informal acts by low level officials, courts may simply look up the chain of command to decide whether authorization occurred.

\section{Stage in the governmental process.}

Third, whether conduct is a public act of the sovereign may also depend upon the stage in the governmental process at which the act takes place. ${ }^{112}$ The rationale for this criterion is that a sovereign ordinarily will not allow itself to be bound by agents' statements made prior to completion of the relevant decisionmaking process. Such statements are, by definition, subject to alteration

${ }^{109}$ Dunhill, 425 US at 718-19 (Marshall dissenting) (citations omitted).

${ }^{110}$ Justice White suggested otherwise. See his plurality opinion in Dunhill, 425 US at 695. See also Sharon, 599 F Supp at 544-45 (requiring formal acts). However, the Dunhill dissent, citing precedents that contradicted Justice White's view, aptly pointed out that "an act of state generally takes the form of an executive or legislative step formalized in a decree or measure, [but] that is only because duly constituted governments generally act through formal means. When they do not, their acts are no less the acts of a state." 425 US at 718-19 (Marshall dissenting) (citations omitted).

11 Underhill, 168 US at 252.

112 In a number of Latin American countries, for example, legislative decrees are not. final and do not carry the force of law until they are published. For another example, see Ramirez de Arellano, 745 F2d at 1533-36 (presidential expropriation decree is not an act of state until property is actually seized). 
before they become final, and therefore may not express the sovereign will. Thus, a non-final act could be classified as non-sovereign.

\section{Identity.}

An additional criterion courts should consider is the identity of the official. The level of government rank at which the official functions is irrelevant as long as the official is properly motivated and authorized to bind the state through its public acts. However, a determination of whether an act is undertaken by a high- or lowlevel government official should guide courts in deciding how much evidence of authorization is required to prove an act was public. For instance, if the Secretary of State issues a policy statement, courts need not ordinarily search up the chain of command to find authorization. ${ }^{113}$ If the conduct of a low-level official is involved, however, courts should inquire more aggressively into whether a more senior official approved the conduct in dispute. ${ }^{114}$

\section{Application of the Proposed Approach}

The facts of Galu $v$ Swissair, ${ }^{115}$ a recent Second Circuit decision, illustrate how the method this Comment proposes for identifying acts of state should work. Galu, an employee of the United Nations High Commission for Refugees, was expelled from Switzerland to the United States, despite her request to be sent to France. She challenged the Swiss expulsion order and the manner in which the Swiss police and Swissair carried it out. She argued that, contrary to the police's action, the order afforded her an opportunity to depart to the country of her choice. ${ }^{116}$ The court remanded the case, directing the district court to require evidence that the police action "had been ordered in the exercise of the sovereign authority of Switzerland" and was not "simply an ad hoc decision of local police officers."117

The court's remand order is consistent with the proposed "public act" definition. ${ }^{118}$ Because Galu's expulsion to the U.S. was

113 In the cases adopting the restrictive view, such as Marcos and DeRoburt, discussed in Section I, no search for authority was needed, because the acts at issue were undertaken by heads of state.

11 See Galu, 873 F2d at 662-63 (requiring evidence of chain of authorization for acts of local police officers).

115873 F2d 650.

116 Id at 651 .

117 Id at 654 (emphasis in original).

118 The court might have decided under Kirkpatrick that the validity of an act of state was at issue and dismissed the suit simply because the parties disputed the proper interpre- 
undertaken pursuant to a formal executive order, the district court did not need to search very far to inquire into the initial authorization for or formality of the act. If the initial decision had been made informally, a greater showing would have been necessary.

However, the existence of a formal order should not end matters, because the alleged act was the police officers' refusal to grant Galu her choice of destination. Swissair might have attempted to show that the act was motivated by the officer's personal animus toward Galu, in order to characterize the act as privately motivated. If improper motives were absent, the court should then have required Swissair to provide evidence of the chain of command authorizing the particular decision by the police to deny Galu a reasonable choice of destination. For example, Swissair might have proved that the local police actions were authorized by demonstrating that the mid-level Swiss official responsible for delegations of authority to the police ordered the police to expel Galu to the United States. If this link in the chain were established, it would be sufficient for the court to deem the act of expulsion a public act. Alternatively, if the movant could not establish prior authorization, the court should allow evidence of subsequent ratification. If no such link were established, however, the "public act" label would not attach, as the sovereign could disclaim responsibility for the ad hoc decision by the local police.

\section{CONCLUSION}

The act of state doctrine must remain a flexible judicial tool for accommodating considerations of comity, separation of powers, and justiciability. Yet it does not follow from this need for flexibility that the doctrine must apply to every type of conduct by foreign officials. Rather, courts should interpret the doctrine to apply only to acts properly attributable to the sovereign. Unauthorized, unratified, or privately motivated acts by foreign officials should not be deemed sovereign acts. The public act element of the act of state doctrine can be measured by the four criteria of authority, formality, stage of governmental process, and the identity of the acting official. This approach will enable courts to dismiss cases that raise the concerns underlying the doctrine, but will help to prevent dismissal of cases that do not jeopardize those concerns.

tation of the executive order. Alternatively, the court might have espoused the expansive view of public act and applied the doctrine regardless of whether the act of expulsion to the U.S. was specifically authorized. 
Defining the "public act" requirement to exclude non-sovereign acts is consistent with the Supreme Court's act of state jurisprudence and the results in several recent lower court decisions, and also reinforces contemporary conceptions of international law. 